\title{
Genetic microstructure in two spanish cat populations. I: genic diversity, gene flow and selection.
}

\author{
Manuel Ruiz-Garcia* and Diana Alvarez \\ Unidad De Genetica (Biologia Evolutiva). Departament De Biologia. Facultad De Ciencias. \\ Pontificia Universidad Javeriana. Cra 7A No 43-82. \\ Bogota D. C. Colombia. \\ Cigeem, Carrer Guatemala No 13 B, C. P: 43882, Segur De Calafell \\ (Tarragona), Catalunya, Spain.
}

(Received 29 September 1999, accepted 31 August 2000)

\begin{abstract}
The genetic microstructure of two Spanish cat populations (in Barcelona and Alicante) was studied. These populations were in Hardy-Weinberg equilibrium at the locus $\underline{\mathrm{O}}$. There was significant genetic heterogeneity for most of the loci studied at the colony level, especially, and the subpopulation level in Barcelona, and at the subpopulation level in Alicante, although the amount of heterogeneity was relatively small compared with that found in other mammal species. Therefore, the major part of the gene diversity found was at the level of the small population structure (colonies). This agrees quite well with high theoretical gene flow estimates.

The Lewontin-Krakauer test showed, in some cases, significant F tests, which appears to indicate the presence of several selective events on some of the loci studied (diversifying and/or unifying), although some other causes, such as differential gene flow, some different historical and demographic parameters at the time of the introduction of the different alleles within the cities studied, as well as different mutation rates of the loci analyzed, could produce significant Lewontin-Krakauer test values, as well.
\end{abstract}

\section{INTRODUCTION}

There are a good number of publications describing the genetic profiles of more than 400 cat populations worldwide. These profiles use genetic markers which code for coloring, pattern, length of fur, and certain skeletal anomalies. Nevertheless, there has been a noteworthy absence of data on the genetic structure of the cat populations at the microgeographic level. Only in recent years has there begun to be a detailed analysis at the microgeographic level as to what type of events could be directing the allelic frequencies in different cat populations in several cities of the world (Ruiz-Garcia, 1988, 1989, 1991, 1993, 1994b, 1998). Notwithstanding, we still do not possess a clear understanding of all of the evolutionary events which could be acting at this microgeographic level, and if they are always of the same nature in cat populations of different cities. Therefore, we were carrying out an in depth analysis of the genetic structure of two cat populations in two Spanish mediterranean cities (Barcelona and Alicante). The analysis of

Edited by Naoyuki Takahata

* Corresponding author. E-mail: mruiz@javercol.javeriana.edu co
Barcelona's population is especially detailed, since it was possible to identify different subpopulations of cats that were isolated from each other there, making it possible to divide them on a still smaller geographical scale, using such defined sample structures as "colonies". In the case of the city of Alicante, it was only possible to perform the analysis at the subpopulational level, because the sampling was insufficient to determine the colony structure. The main microgeographic aspects which interested us in relation to the genetic structure of the cat populations of these two cities were as follows:

1/ To analyze the Hardy-Weinberg equilibrium at thelocus, at the colonial (in Barcelona), as well as at subpopulation levels (Barcelona and Alicante). 2/ To analyze the genetic diversity, heterogeneity, and the gene flow in the different defined sample structures in both these cities. 3/ To analyze by means of Lewontin and Krakauer's test (1973) the possible differential variance of the distributions of the allele frequencies of the genes studied, and, therefore, the possibility of the existence of diversifying and/or unifying selection affecting in various ways the alleles analyzed. In order to do this, we used different allele sets. 4/ To analyze whether the results obtained by this analysis were in agreement with the reported data 
from studies of the ecology, ethology and reproductive biology of this species.

Previous studies of the distribution of genetic variation in natural populations showed that differences are often greater at the microgeographic level than at coarser levels of structure. In fact, it may well be that in some mammalian (and other) species differentiation at the microgeographic level is the norm rather than the exception (Smith et al. 1978; Varvio-Aho and Pamilo, 1980; Lorenzini et al. 1993; Preleuthner and Pinsker, 1993). The populations of many mammals appear to share a higher demic structure, with subpopulations divided into lineages. This has the effect of producing significant endogamy and largely limits the gene flow between these lineages (for instance, see Nevo et al. 1992). Some of these studies have demonstrated that the effective number of these lineages (or demes or colonies) can be very small (DeFries and McClearn, 1972; Patton \& Feder, 1981) and the relative importance of the stochastic processes in determining allelic frequencies can be very important. Immigrants introduced into such population structures have relatively little chance to influence the reproductive outcome, and so there is very little gene flow. The opposite conclusions have been reached in other studies (Jackson and Pounds, 1979; Baker, 1981; Lidecker and Patton, 1987; Berry et al. 1990), where gene flow was observed to be important in social species. In populations of domestic cats, social interactions appear to have great importance (Kerby and Macdonald, 1988; Liberg and Sandell, 1988; Natoli and De Vito, 1988) and together with the reproductive structure of this species and with the actions of human beings as a powerful dispersion vector, it would be expected that the microgeographic structure of cat populations would conform with this second option. Nevertheless, although the human species can actively disperse cats, in order for the gene flow to be effective, it is necessary that the individuals that come to the new locality be able to interact reproductively with the individuals peculiar to the place. Therefore, the cats' social reproductive structure has to be flexible and "open" to accept foreign animals as reproductive elements. The genetic results obtained seem to agree quite well with this second kind of structure.

\section{MATERIALS AND METHODS}

Characters studied and areas sampled. The phenotypes of the cats were recorded directly from observations of animals. The genetic nomenclature used is in accordance with the Committee on Standardized Genetic Nomenclature for Cats (1968). The genetic characteristics studied here included: a gene sex-linked $(\underline{O}, \underline{0}$; Orange [Mutant, all pigment is orange; epistatic to the A locus] vs non-orange [Wild; pigmentation no orange]) and the autosomical loci, A ( $\underline{\mathrm{A}}, \underline{\text { a }}$; Agouti [Wild; Agouti color] vs Non-agouti [Mutant recessive; Non-agouti color, black colour; epistatic to the $\mathrm{T}$ locus]), $\mathrm{T}\left(\underline{\mathrm{t}}^{ \pm}, \underline{\mathrm{t}}^{\mathrm{b}}, \mathrm{T}^{\mathrm{a}}\right.$; striped or mackerel tabby [Wild; recessive to $T^{a}$ but dominant to $\underline{\underline{b}}^{\underline{ }}$ ] vs blotched tabby [Mutant recessive] vs Abyssinian tabby [Mutant dominant]), D ( $\underline{\mathrm{D}}, \underline{\mathrm{d}}$; Dense colour [Wild] vs Dilution [Mutant recessive; dilute colour]), L $\underline{\mathrm{L}}, \underline{1}$; Short hair [Wild] vs Long hair [Mutant recessive]), $\mathbf{S}(\underline{\mathbf{S}}, \mathbf{S}$; Piebald white spotting [Mutant dominant] vs Non-piebald white spotting [Wild]), W ( $\underline{\mathrm{W}}, \underline{\mathrm{w}}$; Dominant white [Mutant dominant; epistatic to all the other colours] vs normal colour [Wild]), C $\left(\underline{\mathrm{C}}, \underline{\underline{c}}^{\underline{\mathrm{s}}}\right.$; full colour [Wild] vs Siamese colour [Mutant recessive]) and $\mathrm{M}(\underline{\mathrm{M}}, \underline{\mathrm{m}}$; Manx [without tail; Mutant dominant; lethal homozygote] vs normal tail [Wild]). The inheritance of all of these characters follows simple Mendelian patterns which permits the easy calculation of allelic frequencies at the respective loci and they have been previously discussed in detail by Robinson (1959, 1977) and Wright and Walters (1982).

Most of this work was done using the seven most commonly studied loci (O, A, T, D, L, S and W), which allows for comparison with previous studies. We introduce the use of the $\mathrm{M}$ and $\mathrm{C}$ loci (where they were observed) in certain analyses, as these two loci represent recent "exotic" additions to the genetic variance of the observed populations, and allow us to observe the introgression of foreign genes. Data on the phenotypes of the cats of Barcelona and Alicante were obtained by direct observations of individual animals in their "home" territories. Each cat was identified with a particular colony or subpopulation without any doubt. A photographic register of every cat was compiled. Each cat sampled was a stray, an alley-cat, a feral cat or "pseudowild". The colonial level in Barcelona was defined as the cats observed at fixed locations and which probably consisted of a few phylopatric female groups inhabiting a small ranging and clearly separated from other such populations by geographical distances ranging from 1000 to $7500 \mathrm{~m}$, approximately, with a mean value of 4212 $\mathrm{m}$. Defined in this way, the number of colonies studied in Barcelona was eleven. The subpopulational level was defined as the groups of colonies inhabiting neighbouring areas clearly separated from each other by geographic barriers (average separation distance was about 5-6 Km). For instance, there were subpopulations separated by 30 or more roads with very intense traffic as an artificial barrier. Defined in this way, we were able to define five subpopulations in Barcelona and four in Alicante. In Alicante, no further division of the population was possible (see Figure 1).

Hardy-Weinberg equilibrium. The Hardy-Weinberg equilibrium was analyzed at the $\underline{O}$ locus, because at this locus, one can determine the genotypic frequencies of homo- and heterozygotes. To test random mating at this locus, a G test was performed (Sokal and Rohlf, 1981). 

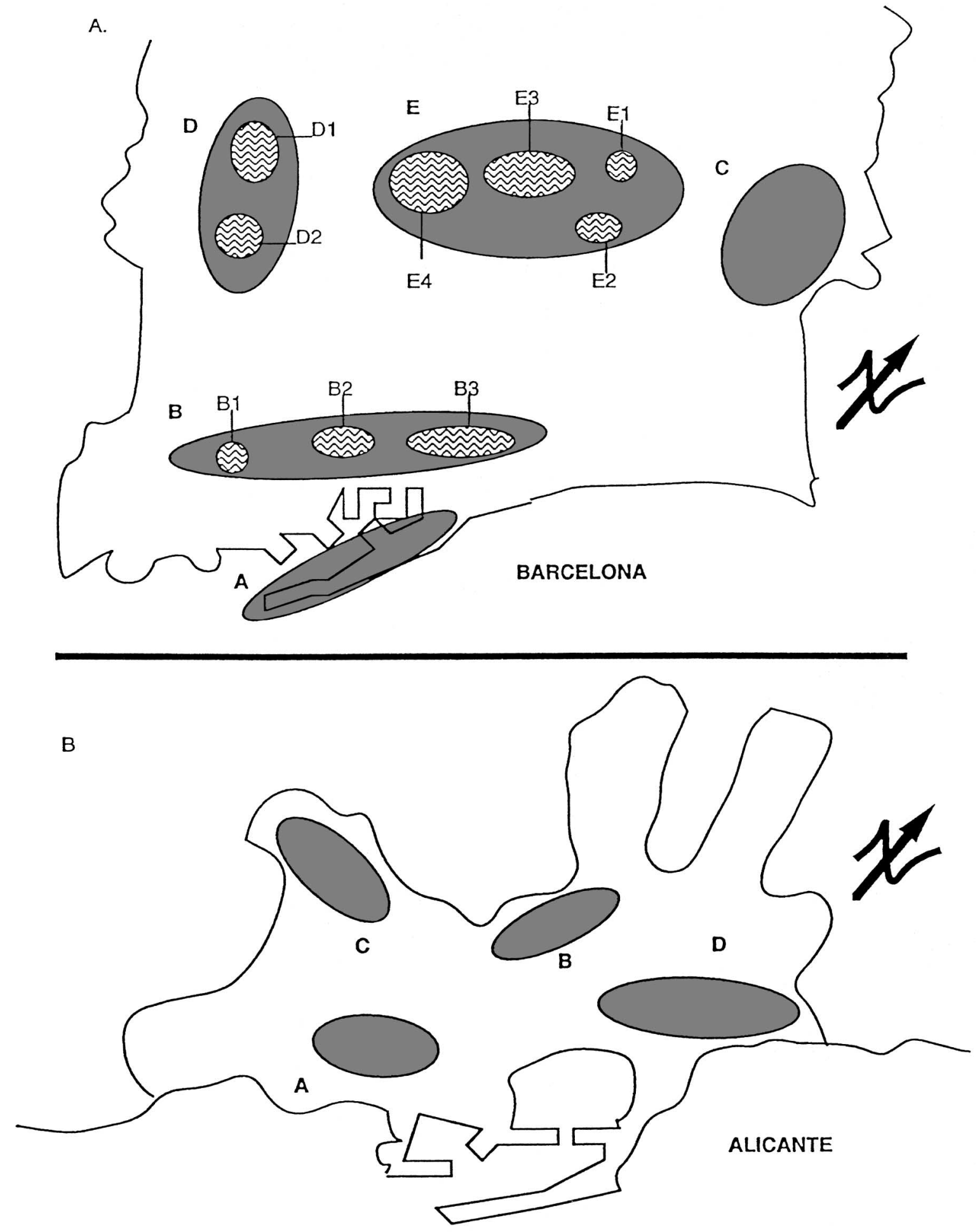

Fig. 1. Maps of cat colonies and subpopulations in Barcelona and in Alicante

Analysis of genic diversity and gene flow. For this purpose, we carried out a Nei's $(1973,1987)$ genic diversity analysis. For each of the sampled loci at the subpopulation level in Barcelona and Alicante, we calculated the following statistics: $\mathrm{H}_{\mathrm{t}}$ (genic diversity in the total population), $H_{s}$ (average gene diversity within subpopulations), $G_{\text {st }}$ (Gene differentiation between subpopulations relative to the gene diversity in the total population), and $\mathrm{Dm}$ (the absolute intersubpopulational gene diversity).

A hierarchical gene diversity analysis was conducted in 
Table 1. Genetic profiles of cat subpopulations and colonies studied in Barcelona and Alicante. * Alleles: $\mathrm{O}=$ orange (sex-linked), $\mathrm{a}=$ non-agouti, $\mathrm{t}^{\mathrm{b}}=$ blotched tabby pattern, $\mathrm{d}=$ dilute color, $\mathrm{l}=$ long hair, $\mathrm{S}=$ piebald white spotting, $\mathrm{W}=$ dominant white. \# $\mathrm{s}=$ subpopulations, $\mathrm{c}=$ colonies.

\begin{tabular}{|c|c|c|c|c|c|c|c|c|}
\hline \multirow{3}{*}{$\begin{array}{l}\text { POPULATIONS } \\
\text { BARCELONA } \\
\text { subpopulations } \\
\text { and colonies }\end{array}$} & \multicolumn{8}{|c|}{ ALLELES* } \\
\hline & Sample & $\mathrm{O}$ & $\mathrm{a}$ & $t^{b}$ & $d$ & 1 & $\mathrm{~S}$ & $\mathrm{~W}$ \\
\hline & Size & & & & & & & \\
\hline A (s.c)\# & 64 & 0.24 & 0.73 & 0.37 & 0.22 & 0.12 & 0.19 & 0.008 \\
\hline $\mathrm{B}(\mathrm{s})$ & 179 & 0.16 & 0.69 & 0.28 & 0.28 & 0.07 & 0.27 & 0.003 \\
\hline $\mathrm{B} 1(\mathrm{c})$ & 31 & 0.27 & 0.65 & 0 & 0.37 & 0 & 0.28 & 0 \\
\hline $\mathrm{B} 2(\mathrm{c})$ & 66 & 0.14 & 0.71 & 0.34 & 0.18 & 0 & 0.27 & 0 \\
\hline B3(c) & 82 & 0.12 & 0.68 & 0.30 & 0.31 & 0.11 & 0.26 & 0.006 \\
\hline C(s.c) & 50 & 0.10 & 0.67 & 0.33 & 0.32 & 0 & 0.39 & 0 \\
\hline $\mathrm{D}(\mathrm{s})$ & 100 & 0.11 & 0.68 & 0.27 & 0.25 & 0.10 & 0.25 & 0 \\
\hline $\mathrm{D} 1(\mathrm{c})$ & 39 & 0.13 & 0.68 & 0.31 & 0.32 & 0 & 0.28 & 0 \\
\hline $\mathrm{D} 2(\mathrm{c})$ & 61 & 0.10 & 0.68 & 0.25 & 0.18 & 0.13 & 0.23 & 0 \\
\hline $\mathrm{E}(\mathrm{s})$ & 316 & 0.17 & 0.70 & 0.23 & 0.26 & 0.17 & 0.27 & 0.005 \\
\hline $\mathrm{E} 1(\mathrm{c})$ & 34 & 0.25 & 0.65 & 0 & 0.25 & 0 & 0.44 & 0 \\
\hline $\mathrm{E} 2(\mathrm{c})$ & 30 & 0.07 & 0.65 & 0.42 & 0.33 & 0.32 & 0.33 & 0.035 \\
\hline E3(c) & 143 & 0.20 & 0.74 & 0.12 & 0.31 & 0.17 & 0.23 & 0 \\
\hline $\mathrm{E} 4(\mathrm{c})$ & 109 & 0.13 & 0.68 & 0.29 & 0.17 & 0.14 & 0.26 & 0.005 \\
\hline \multicolumn{9}{|l|}{$\begin{array}{l}\text { ALICANTE } \\
\text { subpopulations }\end{array}$} \\
\hline A & 67 & 0.32 & 0.85 & 0.34 & 0.28 & 0 & 0.15 & 0 \\
\hline B & 96 & 0.18 & 0.82 & 0.67 & 0.11 & 0 & 0.27 & 0 \\
\hline $\mathrm{C}$ & 52 & 0.18 & 0.76 & 0.31 & 0.28 & 0 & 0.34 & 0.01 \\
\hline $\mathrm{D}$ & 120 & 0.24 & 0.79 & 0.46 & 0.24 & 0 & 0.44 & 0.008 \\
\hline
\end{tabular}

Table 2. G test (Sokal and Rohlf 1981) for Hardy-Weinberg equilibrium at the Orange locus in Barcelona and Alicante cat populations. * Population identifiers as in Table 1. $\mathrm{O} /$ ? = orange color, sex unknown; $\mathrm{O} /+$ = orange and black females; $+/$ ? = black, sex unknown. $\mathrm{p}(\mathrm{O})=$ Orange frequencies.

\begin{tabular}{|c|c|c|c|c|c|c|c|c|}
\hline & \multicolumn{3}{|c|}{ Observed } & \multicolumn{3}{|c|}{ Expected } & \multirow[b]{2}{*}{$\mathrm{p}(\mathrm{O})$} & \multirow[b]{2}{*}{ G } \\
\hline & $\mathrm{O} / ?$ & $\mathrm{O} /+$ & $+/ ?$ & $\mathrm{O} / ?$ & $\mathrm{O} /+$ & $+/ ?$ & & \\
\hline \multicolumn{9}{|c|}{ BARCELONA } \\
\hline TOTAL & 65 & 90 & 539 & 63.72 & 92.56 & 537.72 & 0.159 & 0.0872 \\
\hline $\mathrm{A}^{*}$ & 9 & 12 & 42 & 9.28 & 11.43 & 42.29 & 0.238 & 0.0402 \\
\hline B & 15 & 25 & 137 & 15.88 & 3.22 & 137.90 & 0.155 & 0.1872 \\
\hline B1 & 7 & 3 & 21 & 5.41 & 6.17 & 19.42 & 0.274 & 2.5619 \\
\hline B2 & 4 & 10 & 51 & 5.12 & 7.75 & 52.13 & 0.138 & 0.8860 \\
\hline B3 & 4 & 12 & 65 & 5.61 & 8.76 & 66.62 & 0.123 & 1.6260 \\
\hline $\mathrm{C}$ & 2 & 6 & 42 & 2.75 & 4.50 & 42.75 & 0.100 & 0.6980 \\
\hline $\mathrm{D}$ & 7 & 8 & 84 & 6.11 & 9.78 & 83.11 & 0.111 & 0.4760 \\
\hline D1 & 4 & 2 & 33 & 2.82 & 4.36 & 31.82 & 0.128 & 1.0410 \\
\hline D2 & 3 & 6 & 52 & 3.35 & 5.49 & 52.15 & 0.100 & 0.0845 \\
\hline $\mathrm{E}$ & 32 & 39 & 234 & 30.09 & 42.79 & 232.12 & 0.168 & 0.4760 \\
\hline E1 & 6 & 4 & 22 & 5 & 6 & 21 & 0.250 & 0.9906 \\
\hline $\mathrm{E} 2$ & 1 & 2 & 24 & 1.07 & 1.85 & 24.07 & 0.074 & 0.0166 \\
\hline E3 & 17 & 21 & 101 & 16.47 & 22.06 & 100.48 & 0.198 & 0.0687 \\
\hline $\mathrm{E} 4$ & 8 & 12 & 87 & 7.91 & 12.16 & 86.92 & 0.131 & 0.0007 \\
\hline \multicolumn{9}{|c|}{ ALICANTE } \\
\hline TOTAL & 48 & 52 & 223 & 45.58 & 57.05 & 220.48 & 0.229 & 0.6196 \\
\hline A & 13 & 16 & 37 & 13.84 & 14.32 & 37.85 & 0.318 & 0.2625 \\
\hline B & 12 & 8 & 70 & 9.42 & 13.15 & 67.43 & 0.177 & 3.0976 \\
\hline $\mathrm{C}$ & 5 & 8 & 37 & 5.31 & 7.38 & 37.31 & 0.180 & 0.0710 \\
\hline $\mathrm{D}$ & 18 & 19 & 80 & 16.98 & 21.03 & 78.99 & 0.235 & 0.2746 \\
\hline
\end{tabular}


Barcelona, where we defined three levels of structure (total population, subpopulation and colony). We calculated the statistical values of $\mathrm{H}_{\mathrm{c}}$ (average gene diversity within colonies), $\mathrm{D}_{\mathrm{cs}}\left(=\mathrm{H}_{\mathrm{s}}-\mathrm{H}_{\mathrm{c}}\right.$; average gene diversity between colonies relative to the gene diversity in the subpopulations), $\mathrm{G}_{\mathrm{cs}(\mathrm{t})}\left(=\mathrm{D}_{\mathrm{cs}} / \mathrm{H}_{\mathrm{t}}\right.$; the relative degree of gene differentiation attributable to colonies within subpopulations relative to the gene diversity in the total population), $\mathrm{G}_{\mathrm{cs}}\left(=\mathrm{D}_{\mathrm{cs}} / \mathrm{H}_{\mathrm{s}}\right.$; genic differentiation attributable to colonies within subpopulations relative to the subpopulational gene diversity). These statistical values satisfy the following relationships:

$$
\begin{aligned}
& \mathrm{H}_{\mathrm{t}}=\mathrm{H}_{\mathrm{c}}+\mathrm{D}_{\mathrm{cs}}+\mathrm{D}_{\mathrm{st}} \text { and }\left(1-\mathrm{G}_{\mathrm{cs}}\right)\left(1-\mathrm{G}_{\mathrm{st}}\right) \mathrm{H}_{\mathrm{t}}=\mathrm{H}_{\mathrm{c}} \text { and } \mathrm{H}_{\mathrm{c}} / \mathrm{H}_{\mathrm{t}} \\
& +\mathrm{D}_{\mathrm{cs}} / \mathrm{H}_{\mathrm{t}}+\mathrm{D}_{\mathrm{st}} / \mathrm{H}_{\mathrm{t}}=1 .
\end{aligned}
$$

In Barcelona, for those subpopulations which could be divided into colonies, we calculated the statistical values of $\mathrm{H}_{\mathrm{si}}$ (gene diversity in the total $\underline{\mathrm{i}}$ subpopulation), $\mathrm{H}_{\mathrm{csi}}$ (average gene diversity of the colonies within a i subpopulation), $\mathrm{G}_{\mathrm{csi}}$ (gene diversity between colonies relative to the total genetic diversity within a subpopulation), and $\mathrm{Dm}_{\mathrm{csi}}$ (absolute gene diversity of colonies within single subpopulations).

In addition in this study, the $\mathrm{F}_{\mathrm{st}}$ statistical value, cor-

Table 3. Analysis of genetic diversity and gene flow within Barcelona and Alicante cat subpopulations. O= orange (sex-linked), $\mathrm{a}=$ non-agouti, $\mathrm{t}^{\mathrm{b}}=$ blotched tabby pattern, $\mathrm{d}=$ dilute color, $\mathrm{l}=$ long hair, $\mathrm{S}=$ piebald white spotting, $\mathrm{W}=$ dominant white,

\begin{tabular}{|c|c|c|c|c|c|c|c|c|c|}
\hline \multicolumn{10}{|c|}{ A. BARCELONA } \\
\hline & $\mathrm{H}_{\mathrm{t}}$ & $\mathrm{H}_{\mathrm{s}}$ & $\mathrm{D}_{\mathrm{st}}$ & $\mathrm{G}_{\mathrm{st}}$ & $\mathrm{F}_{\mathrm{st}}$ & $\chi^{2}$ & $\mathrm{df}$ & $\mathrm{D}_{\mathrm{m}}$ & $\operatorname{Nm} \alpha$ \\
\hline $\mathrm{O}$ & 0.2667 & 0.2643 & 0.0024 & 0.0089 & 0.0082 & $11.387^{*}$ & 4 & 0.0029 & 19.342 \\
\hline $\mathrm{a}$ & 0.4231 & 0.4225 & 0.0005 & 0.0013 & 0.0005 & 0.644 & 4 & 0.0007 & 311.260 \\
\hline tb & 0.3959 & 0.3923 & 0.0036 & 0.0090 & 0.0077 & 5.901 & 4 & 0.0046 & 20.608 \\
\hline d & 0.3896 & 0.3886 & 0.0010 & 0.0026 & 0.0019 & 2.662 & 4 & 0.0013 & 83.013 \\
\hline $\mathrm{L}$ & 0.2113 & 0.2058 & 0.0055 & 0.0260 & 0.0253 & $35.335^{* *}$ & 4 & 0.0069 & 6.170 \\
\hline $\mathrm{S}$ & 0.3916 & 0.3884 & 0.0032 & 0.0082 & 0.0075 & $10.417^{*}$ & 4 & 0.0040 & 21.158 \\
\hline W & 0.0071 & 0.0071 & 0.0000 & 0.0014 & 0.0007 & 1.073 & 4 & 0.0000 & 208.153 \\
\hline \multicolumn{10}{|c|}{ Mean (7 loci) } \\
\hline & 0.2979 & 0.2955 & 0.0023 & 0.0082 & 0.0074 & $67.422^{* *}$ & 28 & 0.0029 & - \\
\hline & \pm 0.0751 & \pm 0.0749 & \pm 0.0009 & \pm 0.0043 & \pm 0.0043 & & & \pm 0.0012 & - \\
\hline M & 0.0071 & 0.0071 & 0.0000 & 0.0036 & 0.0029 & 4.078 & 4 & 0.0000 & 54.677 \\
\hline$c^{s}$ & 0.1865 & 0.1798 & 0.0067 & 0.0358 & 0.0351 & $49.440 * *$ & 4 & 0.0083 & 4.403 \\
\hline \multicolumn{10}{|c|}{ Mean (9 loci) } \\
\hline & 0.2532 & 0.2507 & 0.0025 & 0.0108 & 0.0099 & $120.940 * *$ & 36 & 0.0032 & - \\
\hline & \pm 0.0819 & \pm 0.0817 & \pm 0.0012 & \pm 0.0060 & \pm 0.0060 & & & \pm 0.0015 & - \\
\hline \multicolumn{10}{|c|}{ Direct value } \\
\hline $\begin{array}{l}\text { Dir } \\
\text { for }\end{array}$ & $\begin{array}{l}\text { ct value } \\
\text { loci }\end{array}$ & & & 0.0100 & & & & 0.0032 & 15.862 \\
\hline \multicolumn{10}{|c|}{ B. ALICANTE } \\
\hline & $\mathrm{H}_{\mathrm{t}}$ & $\mathrm{H}_{\mathrm{s}}$ & $\mathrm{D}_{\mathrm{st}}$ & $\mathrm{G}_{\mathrm{st}}$ & $\mathrm{F}_{\mathrm{st}}$ & $\chi^{2}$ & $\mathrm{df}$ & $\mathrm{D}_{\mathrm{m}}$ & $\operatorname{Nm} \alpha$ \\
\hline $\mathrm{O}$ & 0.3515 & 0.3460 & 0.0054 & 0.0155 & 0.0140 & $9.064^{*}$ & 3 & 0.0073 & 9.882 \\
\hline $\mathrm{a}$ & 0.3179 & 0.3163 & 0.0016 & 0.0052 & 0.0034 & 1.893 & 3 & 0.0022 & 40.710 \\
\hline tb & 0.4981 & 0.4630 & 0.0350 & 0.0703 & 0.0668 & $19.127^{*}$ & 3 & 0.0467 & 1.857 \\
\hline d & 0.3408 & 0.3306 & 0.0102 & 0.0299 & 0.0284 & $18.351^{*}$ & 3 & 0.0136 & 4.810 \\
\hline $\mathrm{L}$ & 0 & 0 & 0 & 0 & 0 & - & 3 & 0 & - \\
\hline $\mathrm{S}$ & 0.4321 & 0.4084 & 0.0237 & 0.0548 & 0.0532 & $34.422^{*}$ & 3 & 0.0315 & 2.498 \\
\hline W & 0.0092 & 0.0091 & 0.0000 & 0.0043 & 0.0028 & 1.807 & 3 & 0.0000 & 50.594 \\
\hline \multicolumn{10}{|c|}{ Mean (7 loci) } \\
\hline & 0.2785 & 0.2677 & 0.0108 & 0.0257 & 0.0241 & $84.665^{*}$ & 21 & 0.0145 & - \\
\hline & \pm 0.0984 & \pm 0.0933 & \pm 0.0067 & \pm 0.0137 & \pm 0.0133 & - & - & \pm 0.0090 & - \\
\hline$c^{\mathrm{s}}$ & 0.2556 & 0.2469 & 0.0087 & 0.0340 & 0.0325 & $21.567^{*}$ & 3 & 0.0116 & 3.997 \\
\hline \multicolumn{10}{|c|}{ Mean (8 loci) } \\
\hline & 0.2756 & 0.2650 & 0.0106 & 0.0268 & 0.0252 & $106.232 *$ & 24 & 0.0141 & - \\
\hline & \pm 0.0912 & \pm 0.0864 & \pm 0.0063 & \pm 0.0128 & \pm 0.0124 & - & - & \pm 0.0084 & - \\
\hline \multicolumn{10}{|c|}{ Direct value } \\
\hline for & loci & & & 0.0390 & & & & & 5.690 \\
\hline \multicolumn{10}{|c|}{ Direct value } \\
\hline for & loci & & & 0.0384 & & & & & 5.448 \\
\hline
\end{tabular}
$\mathrm{M}=\operatorname{manx}, \mathrm{c}^{\mathrm{s}}=$ Siamese. ${ }^{*}$

$* \mathrm{p}<0.05, * * \mathrm{p}<0.001$ 
rected for sampling error by using Workman and Niswander's (1970) method ( $\mathrm{F}_{\mathrm{st}}$ '), was calculated as well. The estimates of $\mathrm{F}_{\text {st }}$ were tested for significant deviation from 0 using the equation:

$\chi^{2}=2 \mathrm{~N}_{\mathrm{t}} \mathrm{F}_{\mathrm{st}}(\mathrm{k}-1)$ with $(\mathrm{k}-1)(\mathrm{s}-1)$ degrees of freedom, where $\mathrm{N}_{\mathrm{t}}$ is the total sample size, $\mathrm{k}$ is the number of alleles, and $\mathrm{s}$ is the number of subpopulations. To quantify the possible differences in heterogeneities introduced by each locus, the F-test of Fisher and Snedecor (Workman and Niswander, 1970) was used.

By using the $\mathrm{F}_{\mathrm{st}}$ statistic, we obtained indirect estimates of $\mathrm{Nm}$, the product of effective population size for the migratory rate per generation, by the $\mathrm{n}$-dimensional island model (Takahata, 1983; Crow and Aoki, 1984), where $\mathrm{Nm}_{\alpha}=\left[\left(1 / \mathrm{G}_{\mathrm{st}}\right)-1\right] / 4[\mathrm{n} /(\mathrm{n}-1)]^{2}, \underline{\mathrm{n}}$ being the number of subpopulations, or colonies, considered.

Selection analysis. In order to verify globally whether any type of selection has any sort of important effect on the genetic structure in the different microgeographic levels analyzed in the cat populations of Barcelona and Alicante, the Lewontin-Krakauer test (1973) was used. The theoretical basis of this test depends on the non-existence of significant heterogeneity in the $\mathrm{F}_{\text {st }}$ values analyzed in the sample groups under consideration if this variation is due to stochastic processes affecting the same parameters and/or interpopulational gene flow, since those events would have to affect all the loci equally (Wood, 1978). In principle, on the contrary, the existence of significant heterogeneity would suggest the presence of selective agents differentially affecting the analyzed loci. We used the value $\mathrm{k}=2$ since this preserves a magnitude that is appropriate for a binomial distribution and for $\mathrm{F}_{\text {st }}$ values between 0 and 0.05 (Nevo, 1973). We applied this test to different loci arrays, including and excluding $\underline{\mathrm{W}}$, which is apparently under the control of uniformly negative selection-mutation equilibrium (Bergsma and Brown, 1971; Todd et al. 1977), an including and excluding the $\underline{\mathrm{C}}$ and $\underline{\mathrm{M}}$ loci, which are considered to be genetic characteristics recently introduced in the cat populations through selective human action. However, the criticisms of this test should not be forgotten (Robertson, 1975ab).

\section{RESULTS}

Phenotypic frequencies, gene frequencies and Hardy-Weinberg equilibrium. The genetic profiles of the cat populations of Barcelona and Alicante, broken down into subpopulations and colonies, is given in Table 1. In the case of Alicante, the M locus was not scored. Analysis of these data for Hardy-Weinberg equilibrium at the $\underline{O}$ locus with the application of a G test is summarized in Table 2. There was no significant statistical deviation between the observed proportions and those expected for Hardy-Weinberg equilibrium at the $\underline{\mathrm{O}}$ locus for any of the colonies studied in Barcelona or for any of the subpopulations studied in Barcelona and Alicante.

Genetic diversity, heterogeneity and theoretical gene flow. In Table 3, we present the genic diversity analysis of the cat subpopulations in Barcelona and

Table 4. Gene diversity attributable to colonies within subpopulations and total population and gene flow between colonies in the cat population of Barcelona. $\mathrm{df}=$ degree of freedom. $\mathrm{O}=$ orange (sex-linked), $\mathrm{a}=$ non-agouti, $\mathrm{t}^{\mathrm{b}}=$ blotched tabby pattern, $\mathrm{d}=$ dilute color, $\mathrm{l}=$ long hair, $\mathrm{S}=$ piebald white spotting, $\mathrm{W}=$ dominant white, $\mathrm{M}=\mathrm{manx}, \mathrm{c}^{\mathrm{s}}=$ Siamese.

\begin{tabular}{|c|c|c|c|c|c|c|c|c|c|c|}
\hline & $\mathrm{H}_{\mathrm{c}}$ & $\mathrm{D}_{\mathrm{cs}}$ & $\mathrm{G}_{\mathrm{cs}}$ & $\mathrm{G}_{\mathrm{cs}(\mathrm{t})}$ & $\mathrm{D}_{\mathrm{ct}}$ & $\mathrm{G}_{\mathrm{ct}}$ & $\mathrm{F}_{\mathrm{ct}^{\prime}}$ & $\chi^{2}$ & $\mathrm{df}$ & $\operatorname{Nm} \alpha$ \\
\hline $\mathrm{O}$ & 0.2606 & 0.0037 & 0.0139 & 0.0138 & 0.0061 & 0.0227 & 0.0220 & $30.6^{* *}$ & 10 & 9.2 \\
\hline $\mathrm{a}$ & 0.4210 & 0.0015 & 0.0036 & 0.0036 & 0.0021 & 0.0049 & 0.0041 & 5.1 & 10 & 50.6 \\
\hline tb & 0.3679 & 0.0244 & 0.0622 & 0.0617 & 0.0279 & 0.0707 & 0.0736 & $56.4^{* *}$ & 10 & 2.6 \\
\hline $\mathrm{d}$ & 0.3805 & 0.0081 & 0.0209 & 0.0208 & 0.0092 & 0.0235 & 0.0232 & $32.1^{* *}$ & 10 & 8.7 \\
\hline $\mathrm{L}$ & 0.1840 & 0.0074 & 0.0358 & 0.0349 & 0.0129 & 0.0609 & 0.0686 & $95.9 * *$ & 10 & 2.8 \\
\hline $\mathrm{S}$ & 0.3847 & 0.0037 & 0.0094 & 0.0093 & 0.0069 & 0.0176 & 0.0168 & $23.3 * *$ & 10 & 12.1 \\
\hline $\mathrm{W}$ & 0.0070 & 0.0001 & 0.0129 & 0.0129 & 0.0001 & 0.0144 & 0.0136 & $19.0^{*}$ & 10 & 14.9 \\
\hline \multicolumn{11}{|c|}{ Mean (7 loci) } \\
\hline & 0.2886 & 0.0069 & 0.0227 & 0.0225 & 0.0093 & 0.0307 & 0.0317 & $262.5^{* *}$ & 70 & - \\
\hline & \pm 0.0735 & \pm 0.0041 & \pm 0.0101 & \pm 0.0099 & \pm 0.0046 & \pm 0.0125 & \pm 0.0138 & & & \\
\hline \multicolumn{11}{|c|}{ Direct value } \\
\hline for & $\operatorname{ci} 0.0236$ & 0.0234 & & 0.0312 & & & & & 6.3 & \\
\hline M & 0.0071 & 0.0000 & 0.0017 & 0.0017 & 0.0000 & 0.0054 & 0.0046 & 6.5 & 10 & 44.2 \\
\hline$c^{\mathrm{s}}$ & 0.1761 & 0.0037 & 0.0208 & 0.2006 & 0.0104 & 0.0558 & 0.0647 & $91.3^{* *}$ & 10 & 2.9 \\
\hline \multicolumn{11}{|c|}{ Mean (9 loci) } \\
\hline & 0.2448 & 0.0058 & 0.0202 & 0.0199 & 0.0084 & 0.0306 & 0.0324 & $360.3^{* *}$ & 90 & - \\
\hline & 0.1600 & 0.0058 & 0.0200 & 0.0188 & 0.0084 & 0.0250 & 0.0283 & & & \\
\hline \multicolumn{11}{|c|}{ Direct value } \\
\hline for & ci0.0233 & 0.0231 & & 0.0332 & & & & & 6.2 & \\
\hline
\end{tabular}

$* \mathrm{p}<0.05, * * \mathrm{p}<0.001$ 
Table 5. Genetic diversity and gene flow in each individual Barcelona cat subpopulation, where a number of colonies were defined. Gene diversity statistics are defined as in other tables, in this case, for individual subpopulations. $\quad \mathrm{df}=$ degree of freedom. ${ }^{* *}=\mathrm{p}<0.001, *=\mathrm{p}<0.05$.

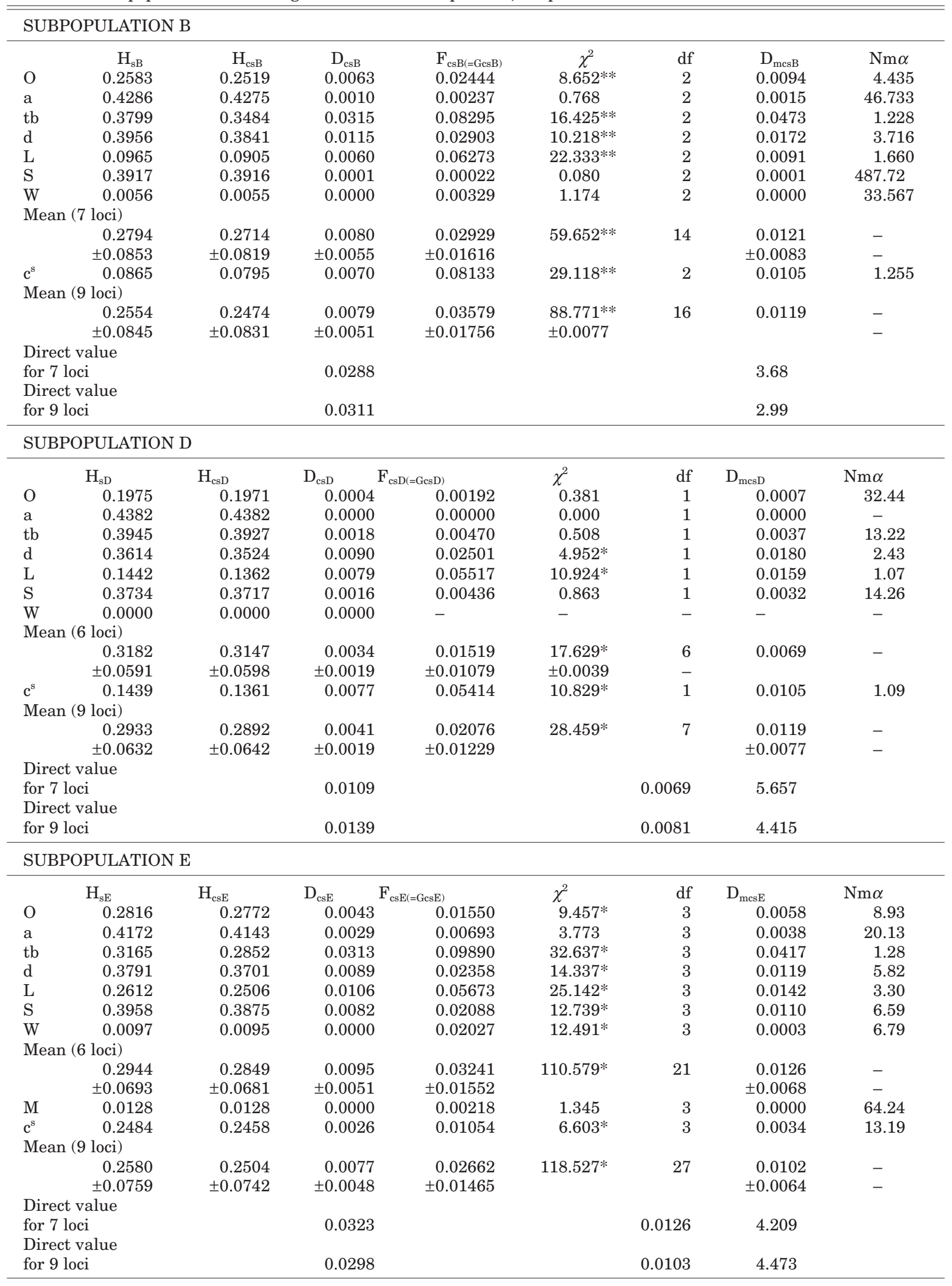


Alicante. The mean value of $\mathrm{F}_{\mathrm{st}}$ ' for the subpopulations of Barcelona (obtained using seven loci) was $0.0074 \pm$ 0.0043. Therefore, each subpopulation has, on average, $99.26 \%$ of the total genic diversity found in the total cat population of Barcelona. Nevertheless, although some $\mathrm{F}_{\text {st }}$ ' and $\mathrm{G}_{\mathrm{st}}$ values were very small, the average value of the seven loci $\left(\overline{\mathrm{F}_{\mathrm{st}}}=0.0074 ; \Sigma \chi^{2}=67.4,28 \mathrm{df}, \mathrm{P}<0.001\right)$ and those for the $\underline{\mathrm{O}}\left(\mathrm{F}_{\mathrm{st}}{ }^{\prime}=0.0082\right), \underline{\mathrm{l}}\left(\mathrm{F}_{\mathrm{st}}{ }^{\prime}=0.0253\right)$ and $\underline{\mathrm{S}}$ $\left(\mathrm{F}_{\mathrm{st}}{ }^{\prime}=0.007\right)$ loci, indicated significant heterogeneity.

The average gene flow estimate $(\mathrm{Nm})$ was 21.4 . Greater mean genetic differentiation was observed among the cat subpopulations of Alicante $\left(\overline{\mathrm{F}_{\mathrm{st}}}=0.0241 \pm\right.$ 0.0136).

Each subpopulation had, on average, $97.59 \%$ of the total genic diversity found in the total Alicante cat population. The average $\mathrm{F}_{\mathrm{st}}$ ' value $\left(\overline{\mathrm{F}_{\mathrm{st}}},=0.0241, \Sigma \chi^{2}=\right.$ 84.7, 21df, $\mathrm{P}<0.001)$ as well as those of the $\underline{\mathrm{O}}\left(\mathrm{F}_{\mathrm{st}}{ }^{\prime}=0.014\right)$, $\underline{\mathrm{t}}^{\underline{\mathrm{b}}}\left(\mathrm{F}_{\mathrm{st}}{ }^{\prime}=0.0668\right), \underline{\mathrm{d}}\left(\mathrm{F}_{\mathrm{st}}{ }^{\prime}=0.0284\right)$ and $\underline{\mathrm{S}}\left(\mathrm{F}_{\mathrm{st}}{ }^{\prime}=0.05321\right)$ alleles were statistically significant. The gene flow estimate $(\mathrm{Nm})$ was 5.7. The introduction in these analyses of "exotic" genes such as $\underline{\underline{c}}^{\underline{\mathrm{s}}}$ and $\underline{\mathrm{M}}$ did not appreciably modify the mean values obtained for the other seven loci.

The gene diversity and the gene flow estimates for colonies within subpopulations of Barcelona can be seen in Table 4. For instance, genic diversity analysis of the cat colonies in Barcelona showed a mean value of $\overline{\mathrm{F}_{\mathrm{ct}}{ }^{\prime}}=0.031$ \pm 0.014 . This value was slightly greater than that at the subpopulational level, but was low compared with the values in other organisms (Ruiz-Garcia, 1991). Each colony had, on average, $96.86 \%$ of the total genic diversity found in the total cat population of Barcelona. At this level, we observed significant heterogeneity in all alleles, except in the a allele, and for the total value of the seven analyzed loci $\left(\overline{\mathrm{F}_{\mathrm{ct}}{ }^{\prime}}=0.0317 ; \Sigma \chi^{2}=262.5,70 \mathrm{df}, \mathrm{P}<0.001\right)$. Some alleles, such as $\underline{\underline{\mathrm{b}}}^{\mathrm{b}}$ and $\underline{1}$,showed significantly more heterogeneity than other alleles such as a and $\underline{\mathrm{W}}$ (F-test of Fisher and Snedecor). The directly estimated gene flow at this sampled level was 6.3.

The especially detailed analysis of the contribution of the defined cat colonies in Barcelona in subpopulations B, $\mathrm{D}$ and $\mathrm{E}$ turned out to be interesting (Table 5). The over- all genetic heterogeneity in those subpopulations due to the contribution of their respective colonies was significant in these three cases (for seven loci in subpopulation $\widehat{\mathrm{B}: \mathrm{F}_{\mathrm{csB}}}=0.0293 \pm 0.0161$; subpopulation D: $\overline{\mathrm{F}_{\mathrm{csD}}}=0.0152 \pm$ 0.0123 ; subpopulation $\left.\mathrm{E}: \overline{\mathrm{F}_{\mathrm{csE}}}=0.0324 \pm 0.015\right)$. Nevertheless, the loci which contributed to this heterogeneity in each case turned out to be very different. In subpopulation $\mathrm{B}$, the loci which yielded significant heterogeneity were $\underline{\mathrm{O}}, \underline{\mathrm{t}^{\mathrm{b}}}, \underline{\mathrm{d}}$ and $\underline{\mathrm{l}}$ (also $\left.\underline{\underline{c}}^{\mathrm{s}}\right)$. The $\mathrm{F}_{\text {csB }}$ values were especially elevated for the $\underline{\mathrm{t}}^{\underline{\mathrm{b}}}(0.0829), \underline{1}(0.0627)$ and $\underline{\mathrm{c}}^{\underline{\mathrm{s}}}$ (0.0813) alleles. In subpopulation $\mathrm{D}$, the alleles which showed significant heterogeneity were $\underline{d}, \underline{l}$ and $\underline{\underline{s}}$, with the last two being those which had the highest $\mathrm{F}_{\mathrm{csD}}$ values $(0.0552$ and 0.0541 , respectively). In subpopulation $\mathrm{E}$, all of the loci except a yielded significant heterogeneity, with alleles $\underline{\underline{\mathrm{b}}} \underline{\mathrm{b}}$ (0.0989) and 1 (0.0567) being especially outstanding. This interesting finding established that a recently introduced allele like $\underline{\underline{s}}^{\underline{s}}$ showed an appreciable heterogeneity in these subpopulations. It is therefore at the colonial level where the stochastic processes can be greater (genetic drift, founder effects), and it is at this level that greater genetic heterogeneity was found.

Selection The selective neutrality of the loci analyzed was tested by the Lewontin and Krakauer (1973) test (Table 6). The results of this test, which is sensitive to heterogeneity in the allele frequencies, are given for various combinations of loci at different levels of structure. In the cat population of Barcelona, at the subpopulation level, the loci $\underline{\mathrm{O}}, \underline{\mathrm{a}}, \underline{\mathrm{t}} \underline{\mathrm{b}}, \underline{\mathrm{d}}, \underline{\mathrm{l}}$, and $\underline{\mathrm{S}}$ showed no significant heterogeneity. When the $\underline{\mathrm{W}}$ locus was added to these, the heterogeneity was marginally significant $(\mathrm{F}(6, \infty)=2.67$, $\mathrm{P}<0.05)$ as it was when the $\underline{\mathrm{C}}$ and $\underline{\mathrm{M}}$ loci were added. This same analysis at the subpopulation level in Alicante did not show statistical significance independently from the groups of loci employed. That is to say, at the subpopulation level in both cities, the loci $\underline{\mathrm{O}}, \underline{\mathrm{A}}, \underline{\mathrm{T}}, \underline{\mathrm{D}}, \underline{\mathrm{L}}$, and $\underline{\mathrm{S}} \operatorname{did}$ not show significant heterogeneity. In contrast to this was the heterogeneity observed at the colonial level in Barcelona. Tests using the six loci above showed significant heterogeneity and the addition of the $\underline{\mathrm{W}}, \underline{\mathrm{M}}$ and $\underline{\mathrm{C}}$ loci

Table 6. Lewontin-Krakauer test applied to Barcelona and Alicante at the subpopulation level. $\mathrm{S}=$ Significant value. $\mathrm{NS}=$ not significant .

\begin{tabular}{cccc}
\hline \hline BARCELONA & & & \\
LEVEL & \# of loci & test L-K $\left(\mathrm{S}^{2} \mathrm{fst} / \mathrm{s}^{2} \mathrm{fst}\right)$ & significance \\
subpopulation & $6(\mathrm{O}, \mathrm{A}, \mathrm{T}, \mathrm{D}, \mathrm{L}, \mathrm{S})$ & 2.149 & $\mathrm{~F}(5,8) \mathrm{NS}$ \\
& $7(\mathrm{O}, \mathrm{A}, \mathrm{T}, \mathrm{D}, \mathrm{L}, \mathrm{S}, \mathrm{W})$ & 2.678 & $\mathrm{~F}(6, \infty) \mathrm{S} \mathrm{p}<0.05$ \\
\hline & $9(\mathrm{O}, \mathrm{A}, \mathrm{T}, \mathrm{D}, \mathrm{L}, \mathrm{S}, \mathrm{W}, \mathrm{M}, \mathrm{C})$ & 2.925 & $\mathrm{~F}(8, \infty) \mathrm{S} \mathrm{p}<0.005$ \\
\hline ALICANTE & \# of loci & test L-K $\left(\mathrm{S}^{2} \mathrm{fst} / \mathrm{s}^{2} \mathrm{fst}\right)$ & significance \\
LEVEL & $6(\mathrm{O}, \mathrm{A}, \mathrm{T}, \mathrm{D}, \mathrm{L}, \mathrm{S})$ & 1.462 & $\mathrm{~F}(5, \infty) \mathrm{NS}$ \\
subpopulation & $7(\mathrm{O}, \mathrm{A}, \mathrm{T}, \mathrm{D}, \mathrm{L}, \mathrm{S}, \mathrm{W})$ & 1.832 & $\mathrm{~F}(6, \infty) \mathrm{NS}$ \\
\hline & $8(\mathrm{O}, \mathrm{A}, \mathrm{T}, \mathrm{D}, \mathrm{L}, \mathrm{S}, \mathrm{W}, \mathrm{C})$ & 1.464 & $\mathrm{~F}(7, \infty) \mathrm{NS}$
\end{tabular}


to these increased the value of $\mathrm{F}$ and made the tests more significant $(\mathrm{P}<0.001)$.

\section{DISCUSSION}

Hardy-Weinberg equilibrium. The analysis of the $\underline{O}$ locus in these two Spanish cities at the microgeographic level showed the probable existence of Hardy-Weinberg equilibrium at this locus. As has been verified in multiple studies in other cat populations (for instance, Lloyd, 1985; Ruiz-Garcia, 1990abcd, 1991; Ruiz-Garcia et al., 1995, 1999), the genetic structure of the cat populations reported here was characterized by not showing clear evolutionary events that cause deviations in the observed genotypic frequencies from those expected in HardyWeinberg equilibrium. Therefore, factors such as selection in favor and/or against the heterozygotes, or endogamy due to breeding among relatives, or positive or negative Wahlund effect due to geographical and/or temporal causes, can be ruled out as events with a determining influence on the cat populations analyzed at the O locus.

Our findings do not necessarily mean that these populations are in perfect Hardy-Weinberg equilibrium (Smith, 1970). Indeed, several tests of the existence of HardyWeinberg equilibrium showed a weak ability to detect type II errors, which, in some cases, do not detect the existence of effective endogamy in the samples analyzed (Ward and Singh, 1970; Pamilo and Varvio-Aho, 1984). It has been shown that in populations where there is not panmixia, multinomial distributions which are very similar to the distributions in perfect Hardy-Weinberg equilibrium can appear (Li, 1988). Furthermore, it was shown that in loci strongly affected by selection, this is not detectable using several current Hardy-Weinberg equilibrium analysis tests (Wallace, 1958; Lewontin and Cockerham, 1959; Li, 1959; Workman, 1969). In addition, inability to reject the null hypothesis does not necessarily indicate that the hypothesis holds, only that the sample size was insufficient for its rejection (Lessios, 1992).

Nevertheless, samples of hundred and thousands of individuals had been analyzed in more than 400 cat populations for these loci and, generally, no significant deviations from the Hardy-Weinberg equilibrium were detected. Some studies with blood allozymes in cat populations of the USA, Israel, Japan and Sweden also showed Hardy-Weinberg equilibrium (O'Brien, 1980; SaliternickVardy et al. 1980; Nozawa et al., 1985; Juneja et al., 1991).

Genic diversity, heterogeneity, gene flow and population structure. In these Iberian populations, at the microgeographic level, the genic diversity of the total populations $\left(\mathrm{H}_{\mathrm{t}}\right)$ differed only slightly from the genic diversity within the subpopulations $\left(\mathrm{H}_{\mathrm{s}}\right)$ or within colonies
$\left(\mathrm{H}_{\mathrm{c}}\right)$. In Barcelona, the amount of diversity introduced by the structure at the colonial level was slighly higher than that at the subpopulation level $\left(\overline{\mathrm{F}_{\mathrm{st}}}=0.0074 \mathrm{vs} . \mathrm{F}_{\mathrm{ct}}=0.031\right)$. It is straightforward to note that the genetic heterogeneity of several loci among the colonies within subpopulation $\mathrm{B}\left(\underline{\mathrm{O}}, \underline{\mathrm{t}^{\mathrm{b}}}, \underline{l}\right.$, and $\left.\underline{\mathrm{d}}\right)$ and within subpopulation $\mathrm{E}\left(\underline{\mathrm{t}}^{\underline{\mathrm{b}}}, \underline{\mathrm{d}}, \underline{1}\right.$ and $\underline{\mathrm{S}}$ ), in the same city, was relatively high. This shows that it is in the colonies that to some relative degree the founder effects and the genetic drift could have a chance to modify the allele frequencies. Nevertheless, the majority of genic diversity was contained within the smallest sample population structures. The observed differentiation in these cat populations was much smaller than that observed for other mammals (Massey and Joule, 1981; Patton and Feder, 1981; Chesser, 1983; Chesser et al, 1982; Navajas y Navarro and Britton-Davidian, 1989; Hartl et al, 1990, 1991; Daley, 1992; Bigalke et al, 1993; Preleuthner and Pinsker, 1993; Lorenzini et al, 1993; Corbet and Robinson, 1991; Corbet et al, 1994). From our results, the smallest sampling unit of population structure contained $95 \%$ of the total genetic variation. Indeed, there seems to be a certain uniformity of the distribution of allelic frequencies which would be hard to explain using strong stochastic processes (drift, founder effects, population bottle-necks), although certain significant genetic heterogeneity was found especially at the colony level in Barcelona. This suggested that the effective population size must be large enough to resist the strong effects of drift. This may be explained by the relatively high levels of gene flow among the populations studied. It is known that populations with high levels of gene flow $(\mathrm{Nm})$ have relatively little population structuring (i.e: Soltis and Soltis, 1989; Ruiz-Garcia, 1994b).

Several comments should be made about the gene flow estimates obtained here. Wright (1943) stated that in an island model if $\mathrm{Nm}>1$ then gene flow is important enough to erase the genetic heterogeneity between the populations in equilibrium. In a stepping-stone model, this value must be larger than 4 (Trexler, 1988). In both models, $\mathrm{Nm}<0.5$ means that the populations are highly isolated. All the estimates of $\mathrm{Nm}$ in this study were very high (colonial level in Barcelona: $\mathrm{Nm}=6.2$; subpopulation level in Barcelona: $\mathrm{Nm}=21.4$; and subpopulation level in Alicante: $\mathrm{Nm}=5.7$ ). However, a significant genetic heterogeneity was observed in all cases. This might be explained according to Allendorf and Phelps (1981), who argued that the most correct interpretation of $\mathrm{Nm}>1$ is that the populations share the same alleles, although not necessarily with the same allele frequencies. By means of simulation models, they showed that significant allele divergence ocurred in $50 \%$ of the generations with gene flow of $\mathrm{Nm}=50$ and that significant allele divergence ocurred on most occasions when $\mathrm{Nm}=10$. The estimates obtained for gene flow at this microgeographic level were probably underestimates of the true values (Ruiz-Garcia, 1991, 1993, 
1997a). These estimates were obtained with highly polymorphic loci and without consideration of the amount of local extinction and recolonization per generation $\left(\mathrm{e}_{0}\right.$, extinction rate per generation, $\underline{\mathrm{k}}$ number of colonists, etc) which can occur in these populations (Ruiz-Garcia, unpublished observations). This has been demonstrated to augment the gene flow in the case of model I of Slatkin (1977) and Wade and McCauley (1988) with the migrant pool. In this model I, migrants move from an external source with a constant gene frequency to an infinite number of local colonies, with migrant pool, where new colonists $(\underline{\mathrm{k}})$ are randomly sampled from the entire population, and if $\mathrm{k}>2 \mathrm{Nm}+0.5$, the $\mathrm{F}_{\mathrm{st}}$ value obtained is smaller (and $\mathrm{Nm}$ is larger) than the $\mathrm{F}_{\mathrm{st}}$ expected without local extinction and recolonization. On the contrary, if the local extinction and recolonization process was generated by model II, where migrants are drawn at random from within a finite array of subdivided populations, with propagule pool, where the new colonies are founded by choosing colonists at random from a single randomly chosen colony, this process will generate $\mathrm{F}_{\text {st }}$ larger than the $\mathrm{F}_{\mathrm{st}}$ expected without extintion and recolonization. Thereby, our values of gene flow $(\mathrm{Nm})$ will be overestimations of the reality.

Selection. The Lewontin-Krakauer test applied to different geographical levels showed diverse results. For example, in Alicante and Barcelona at the subpopulation level, six loci did not present significant values. In the case of Barcelona at the subpopulation level, there were statistically significant differences due to the introduction of $\underline{\mathrm{W}}_{2}$ on the one hand, and $\underline{c}^{\underline{\mathrm{s}}}$ and $\underline{\mathrm{M}}$, on the other hand. This could be attributable to uniform selection against $\underline{\mathrm{W}}$ and $\underline{M}$, because they are alleles, which introduce viability problems in their carriers (Robinson, 1977; Todd et al., 1977; Adalstainsson, 1980). In all the cases, the addition of $\underline{\mathrm{W}}$ increased the values of the ratios $\mathrm{S}^{2}$ Fst $/ \mathrm{s}^{2}$ Fst showing that the heterogeneity of this locus is much lower than those of the remaining six loci, confirming the possible action of uniform selection upon this allele. Nevertheless, significant values were observed at the smallest level, colonies in Barcelona. This should be an indication of selection differentially affecting the loci analyzed. However, the explanation of these the significant values may be of the same nature as some explanations previously expressed. The existence of historic-stochastic factors differentially affecting these loci and the existence of differential gene flow throughout the colonization history of a determined area should produce significant values of the ratio $\mathrm{S}_{\text {Fst }}^{2} / \mathrm{s}_{\text {Fst }}^{2}$, as well. For this reason, significant values in the Lewontin-Krakauer test do not necessarily indicate the existence of differential selection within a loci array analyzed. We agree with the critical comments made about this test (Robertson, 1975ab; Ruiz-Garcia, 1996; Taylor et al, 1995).
Ethological and ecological concerns. The ethology of cats in urban populations has been well studied (Waser and Wiley, 1979; Dards, 1979; Natoli, 1985; Natoli and De Vito, 1988; Kerby and MacDonald, 1988). The correspondence between these studies and the microgeographical data presented here was good. Many of the behavioural characteristics of cats provide good mechanisms to explain the observed levels of gene flow. Cats are territorial but do not hold exclusive territories. Rather, both males and females have overlapping home ranges, with the males having much ranges than the females. In fact, it is primarily males which are responsible for gene flow, as they breed promiscuously with many females over large areas (Leyhausen, 1965; Liberg, 1980, 1983; Izawa et al, 1982; Liberg and Sandell, 1988).

A very important factor in the spatial distribution of cats (and many other carnivores) is the distribution of food sources for the species. As both males and females will congregate near food sources (in the case of cats, there are largely tied to the actions of humans), the availability of food only at specific locations will influence the amount of gene flow. As males enlarge their territories considerably during breeding periods to include many such locations (Corbett, 1979; Izawa et al., 1982), they act as effective agents of gene flow.

Augmenting this behavior is that of the females toward male offspring. The females, and sometimes the resident males, will force pubescent males to leave the colonies of their birth (Liberg, 1980; Izawa et al, 1982; Warner, 1985). These behaviors, coupled with the fact that there is no effective dominance hierarchy for mating success by males (Natoli and De Vito, 1988) tend to increase the amount of gene flow, reduce endogamy, and increase the effective population size. This is in clear contrast to the situation in other mammals with male dispersion (i.e: Scribner et al., 1991, Kurt et al., 1993, Nelson, 1993).

The authors are very grateful to Dr. K. Klein (Mankato, USA), Dr. A. Sanjuan (Vigo, Spain), Dr. J. Jordana (Barcelona, Spain), Dr. R. Robinson (London, England), Dr. A. T. Lloyd (Dublin, Ireland), Dr. R.Fagen (Alaska, USA), Dr. Ph. Dreux (Paris, France) and Dr. J. Ahumada (Bogotá D. C, Colombia) for their assistance and comments. Special thanks go to Dr. J. Jorgenson (Bogotá. DC., Colombia) for help with English syntax. This work was partially supported by the grant Convenio No. 139-94 and No. 140-96 (Decreto 1742 de 1994) from COLCIENCIAS to the authors. This work is dedicated to the memory of Dr. Roy Robinson, a scientist with a great deal of knowlede about mammalian coat genes, who died in 1996. May he rest in peace.

\section{REFERENCES}

Adalsteinsson S. (1980). Establishment of equilibrium for the dominant lethal gene for Manx taillessness in cats. Theor. Appl. Genet. 58, 49-53.

Allendorf FW, Phelps SR. (1981) Use of allelic frequencies to describe population structure. Can. J. Fish. Aquat. Sci. 38, 1507-1514. 
Baker AEM. (1981). Gene flow in house mice: introduction of a new allele into a free-living population. Evolution 35, 243258.

Bergsma DR, Brown KS. (1971). White fur, blue eyes and deafness in the domestic cat. J. Hered. 62, 170-185.

Berry R J, Triggs G S, Bauchau V, Jones CS, Scriven P. (1990). Gene flow and hybridization following introduction of Mus musculus into an established population. Biol. J. Linn. Soc. 41, 279-283.

Bigalke RC, Hartl GB, Berry M P S, Van Hensbergen J. (1993). Population genetics of the springbok Antidorcas marsupialis - a preliminary study. Acta Theriologica (Suppl.2) 38, 103-111.

Chesser R K. (1983). Genetic variability within and among populations of black tailed prairie dog. Evolution 37, 320-331.

Chesser R K, Reuterwall C, Ryman N. (1982). Genetic differentiation of Scandinavian moose, Alces alces, populations over short geographical distances. Oikos 39, 125-130.

Committee on Standardized Genetic Nomenclature for Cats (1968). Standardized genetic nomenclature for the domestic cat. J. Hered. 59, 39-49.

Corbet SW, Grant WS, Robinson TJ. (1994). Genetic divergence in south African Wildebeest: Analysis of allozyme variability. J. Hered. 85, 479-483.

Corbet SW, Robinson TJ. (1991). Genetic divergence in South African wildebeest: comparative cytogenetics and analysis of mitochondrial DNA. J. Hered. 82, 447-452

Corbett LK. (1979). Feeding ecology and social organization of wild cats (Felis silvestris) and domestic cats (Felis catus) in Scotland. Ph.D. Thesis, University of Aberdeen, UK

Crow JF, Aoki K. (1984) Group selection for a polygenic behavioral trait: estimating the degree of population subdivision. Proc. Natl. Acad. Sci. USA 81, 6073-6077.

Dards JL. (1979). The population ecology of feral cats (Felis cattus L.) in Portsmouth dockyard. Ph.D. thesis, University of Southampton, UK.

Daley JG. (1992). Population reductions and genetic variability in black-tailed prairie dogs. J. Wild Life Manage. 56, 212220.

De Fries JC, McClearn GE. (1972). Behavioural genetics and the fine structure of mouse populations: a study in microevolution. Evol. Biol. 5, 279-291.

Hartl GB, Lang G, Klein F, Willing R. (1991). Relationships between allozymes, heterozygosity and morphological characters in red deer (Cervus elaphus), and the influence of selective hunting on allele frequency distributions. Heredity 66, 343-350.

Hartl GB, Willing R, Lang G, Klein F, Koller J. (1990). Genetic variability and differenetiation in red deer (Cervus elaphus L.) of Central Europe. Genetics Selection Evolution 22, 289306.

Izawa M, Doi T, Ono Y. (1982). Grouping patterns of feral cats (Felis cattus) living on a small island in Japan. Jpn. J. Ecol. 32, 373-382.

Jackson JF, Pounds JA. (1979). Comments on assessing the differentiating effects of gene flow. Syst. Zool. 28, 78-85.

Juneja RK, Niini T, Larsson HEB, Sandberg K. (1991). Genetic polymorphism of six plasma proteins in the domestic cat. $J$. Hered. 82, 178-181.

Kerby G, MacDonald DW. (1988). Cat society and the consequences of colony size. In: The domestic cat: The biology of its behaviour. (Turner DC, Batenson P, eds). Cambridge University Press, 67-81.

Kurt F, Hartl GB, Volk F. (1993). Breeding strategies and genetic variation in European roe deer Capreoulus capreolus populations. Acta Theriologica Suppl. 2 38, 187-194.
Lessios HA. (1992). Testing electrophoretic data for agreement with Hardy-Weinberg. Mar Biol 112, 517-523.

Lewontin RC, Cockerham CC. (1959). The goodness-of-fit test for detecting natural selection in random mating populations. Evolution 13, 561-564.

Lewontin RC, Krakauer J. (1973) Distribution of gene frequency as a test of the theory of the selective neutrality of polymorphisms. Genetics 74, 175-195.

Leyhausen P. (1965). The comunal organization of solitary mammals. Symposia of the Zoological Society of London 14, $249-263$

Li CC. (1959). Notes on relatives fitness of genotypes that forms a geometric progression. Evolution 13, 564-567.

Li CC. (1988). Pseudo-random mating populations. In celebration of the 80 th anniversary of the Hardy-Weinberg law. Genetics 119, 731-737

Liberg O. (1980). Spacing patterns of a population of rural free roaming domestic cats. Oikos 35, 336-339.

Liberg O. (1983). Courtship behaviour and sexual selection in the domestic cat. Applied Animal Ethology 10, 117-132.

Liberg O, Sandell M. (1986). Spacing patterns and mating systems in domestic cats and other felids. In: The domestic cat, the biology of its behaviour. (Turner DC, Batensin, P, eds). Cambridge University Press. 82-98.

Lidecker WZ, Patton JL. (1987). Patterns of dispersal and genetic structure in populations of small rodents. In: Mammalian dispersal patterns. (Chepka-Sade BD and Talpin ZT, eds). University of Chicago Press, 144-161

Lloyd AT. (1985). Geographic distribution of mutant alleles in domestic cat populations of New England and the Canadian Maritimes. J. Biogeography 12, 315-322.

Lorenzini R, Patalano M, Apollonio M, Mazzarone V. (1993). Genetic variability of roe deer Capreolus capreolus in Italy: electrophoretic survey on populations of different origin. Acta Theriologica (Suppl. 2) 38, 141-151.

Massey DR, Joule J (1981) Spatial-temporal changes in genetic composition of deer mouse populations. In: Mammalian population genetics. (Smith MH, Joule J, eds). University of Georgia Press, Athens, 180-201.

Natoli E. (1985). Spacing pattern in a population in a colony of urban stray cats (Felis catus L) in the historic centre of Roma. App. Anim. Beh. Sc. 14, 289-304.

Natoli E, DeVito E. (1988). The mating system of feral cats living in a group. In:The domestic cat, the biology of its behaviour. (Turner DC, Batenson P, eds). cambridge University Press, 99-108.

Navajas y Navarro M, Britton-Davidian J. (1989). Genetic structure of insular Mediterranean populations of the house mouse. Biol. J. Linn. Soc. 36, 377-390.

Nei M. (1973). Analysis of gene diversity in subdivided populations. Proc. Natl. Acad. Sci. USA 70, 3321-3323.

Nei M. (1987). Molecular evolutionary genetics. Columbia University Press, New York.

Nelson ME. (1993). Natal dispersal and gene flow in white-tailed deer in northeastern Minnesota. J. Mammal 74, 316-322.

Nevo E (1973). Test of selection and neutrality in natural populations. Nature 244, 573-575.

Nevo E, Ben-Shlomo R, Beiles A, Hart CP, Ruddle FH. (1992). Homeobox DNA polymorphisms (RFLPs) in subterranean Mammals of the Spalax ehrenbergi Superspecies in Israel: Patterns, correlates, and Evolutionary significance. J. Exp. Zool. 263, 430-441.

Nozawa K, Fukui M, Furukawa T. (1985) Blood-protein polymorphism in the Japanese cats. Jpn. J. Genet. 60, 425-439.

O'Brien S J. (1980). The extent and character of biochemical genetic variation in the domestic cat. J. Hered. 71, 2-8. 
Pamilo P, Varvio-Aho S. (1984). Testing genotype frequencies and heterozygosities. Mar. Biol. 79, 99-100.

Patton J L, Feder JH. (1981). Microspatial genetic heterogeneity in pocket gophers: Non-random breeding and drift. Evolution 35, 912-920.

Preleuthuer M, Pinsker W. (1993). Depauperated gene pools in Marmota m. marmota are caused by an ancient bottle neck: electrophoretic analysis of wild populations from Austria and Switzerland. Acta Theriologica (Suppl. 2) 38, 121-139.

Robertson A. (1975a). Remarks on Lewontin-Krakauer test. Genetics 80, 396.

Robertson A. (1975b). Gene frequency distributions as a test of selective neutrality. Genetics 81, 775-805.

Robinson R. (1959). Genetics of domestic cat. Bibliographia Genetica 8, 273-362.

Robinson R. (1977). Genetics for cat breeders. 2nd. ed. Pergamon Press. Oxford.

Ruiz-Garcia M. (1988). Frecuencias alÈlicas mutantes en una poblaciÛn de gatos domÈsticos urbanos (Barcelona) y en una poblaciÛn de gatos rurales (Castelldefels rural) en Cataluña, España. Genét Ibérica 40, 157-187.

Ruiz-Garcia M. (1989). The urban effect in two Spanish domestic cat populations. C. Gene J. 6, 1-26.

Ruiz-Garcia M. (1990a). Mutant allele frequencies in the domestic cat populations in Catalonia, Spain, and their genetic relationships between Spanish and English colonial cat populations. Genetica 82, 209-214.

Ruiz-Garcia M. (1990b). Mutant allele frequencies in the domestic cat populations on the Spanish Mediterranean Coast, and their genetic distances from other European and North African cat populations. Genetica 82, 215-221.

Ruiz-Garcia M. (1990c). Frecuencias alélicas en la población de gatos domésticos de Palma de Mallorca e Ibiza y relaciones genÈticas con poblaciones de gatos europeos y norteafricanos. Evol. Biol. 4, 189-216.

Ruiz-Garcia M. (1990d). Frecuencias alélicas en la población de gatos domésticos de la isla de Menorca (Baleares): diferentes modelos de evolución colonizadora. Evol. Biol. 4, 307-342.

Ruiz-Garcia M. (1991). Más sobre la genética de poblaciones de Felis cattus en la Costa Mediterránea Española: Un análisis de la estructura genética de las poblaciones naturales de gatos. Evol. Biol. 5, 227-283.

Ruiz-Garcia M. 1993. Analysis of the evolution and genetic diversity within and between Balearic and Iberian cat populations. J. Hered. 84, 173-180.

Ruiz-Garcia M. (1994). Genetic structure of Marseilles cat population: Is there really a strong founder effect?. Genetics Selection Evolution 26, 317-331.

Ruiz-Garcia M. (1996). Posee la genética de poblaciones límites explicativos a los procesos de micro y macroevolución?. Academia Colombiana de Ciencias Exactas, Físicas y naturales. Colección Memorias No 8. 11-32.

Ruiz-Garcia M. (1997). Genetic relationships among some new cat populations sampled in Europe: a spatial autocorrelation analysis. J. Genet. 76: 1-24.

Ruiz-Garcia M. (1998). Genetic structure of different cat populations (Felis catus) in Spain, Italy and Argentina at a microgeographic level. Acta Theriologica 43, 39-64.

Ruiz-Garcia M, Ruiz S, Alvarez D. (1995). Perfíles genéticos de poblaciones de gatos domésticos (Felis catus) de la província de Girona (Catalunya, NE, España) y posibles relaciones genéticas con otras poblaciones europeas occidentales. Misc. Zool. 18, 169-196.

Ruiz-Garcia M, Campos HA, Alvarez D, Kajon A, Diaz S. 1999. Coat gene profiles of several cat populations in Cuba,
Costa Rica, Colombia, Paraguay, Chile and Argentina, and possible genetic origins of these cat populations. Genet. Sel. Evol. 32 (in press).

Saliternik-Vardy R, Cohen T, Neufeld E, Ritte U. 1980. Electrophoretic variation in blood proteins of the domestic cat. Carnivore Genet. Newl. 4, 98-107.

Scribner KT, Smith MH, Garrot RA, Carpenter LH. (1991). Temporal, spatial and age-specific changes in genotypic composition of mule deer. J. Mammal 72, 126-137.

Slatkin M. (1977). Gene flow and genetic drift in a species subject to frequent local extinction. Theor. Popul. Biol. 12, 253262.

Smith MH, Manlove MN, Joule J. (1978). Spatial and temporal dynamics of the genetics organization of small mammals populations. In: Populations of small mammals under natural conditions (Snyder DP, ed). Symposium of Ecology, University of Pittsburgh, Pittsburgh.

Smith CAB. (1970). A note on testing the Hardy-Weinberg law. Ann. Hum. Genet. 33, 377-383.

Sokal RR, Rohlf F J. (1981). Biometry. Freeman, San Francisco.

Soltis DE, Soltis PS. (1989). Polyploidy, breeding systems and genetic differentiation in homosporous pteridophytes. In: Isozymes in Plant Biology. (Soltis DE, Soltis PS, eds). Dioscorides Press. Portland.

Takahata N. (1983). Gene identity and genetic differentiation of populations in the finite island model. Genetics 104, 497512.

Taylor MFJ, Shen Y, Kreitman ME. (1995). A population genetic test of selection at the molecular level. Science 270, 14971499.

Todd NB, Sawyer L, Todd LM. (1977). Mutant allele frequencies in the cats of Van, Turkey. Carnivore Genet. Newsl. 3, 161-167.

Trexler JC. (1988). Hierarchical organization of genetic variation in the Sailfin Molly, Poecilia latipinna (Pisces: Poeciliidae). Evolution 42, 1006-1017.

Varvio-Aho SL, Pamilo P. (1980). Genetic differentiation of the northern Finnish water-strider (Gerris) populations. Hereditas 92, 361-363.

Wade MJ, McCauley DE. (1988). Extinction and recolonization: their effects on the genetic differentiation of local populations. Evolution 42, 995-1005.

Wallace B. (1958). The comparison of observed and calculated zygotic distributions. Evolution 12, 113-115.

Ward RH, Sing CF. (1970). A consideration of the power of the $\chi^{2}$ test to detect inbreeding effects in natural populations. Amer. Nat. 104, 355-365.

Warner RE. (1985). Demography and movements of the freeranging domestic cats in rural Illinois. J. Wild Life Manage. 49, 340-346.

Waser PM, Wiley RH. (1979). Mechanisms and evolution of spacing in animals. In: Handbook of Behavioural Neurobiology. Vol 3. (Marler P, Vandenbergh K, eds). Plenum Press, New York.

Wood JW. (1978). Population structure and genetic hetrogeneity in the Upper Markham Valley of New Guinea. Amer. J. Phys. Antrop. 48, 463-470.

Workman PL. (1969). The analysis of simple genetic polymorphisms. Human Biology 41, 97-114.

Workman P L, Niswander JD. (1970). Population studies on the southwestern Indian tribes. II. Local genetic differentiation in the Papago. Amer. J. Hum. Genet. 22, 24-49.

Wright S. (1943). Isolation by distance. Genetics 28, 114-138. Wright M, Walters S. (1982). El gato. Ed. Blume. Barcelona. 